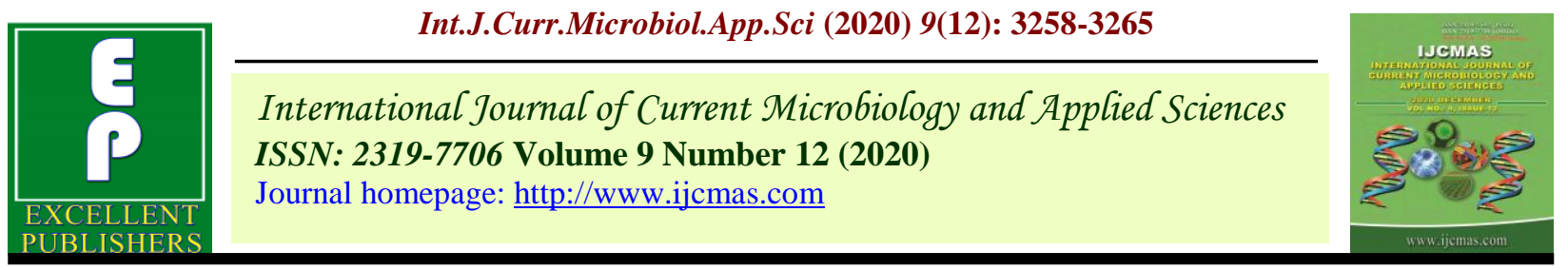

Original Research Article

https://doi.org/10.20546/ijcmas.2020.912.388

\title{
Microbial Quality, Physicochemical and Sensory Properties of Mixed Fruit Juice Subjected to Different Preservation Methods
}

\author{
Noah, Abimbola Aduke* \\ Department of Food Technology, Federal Polytechnic Ilaro, Ogun State, Nigeria \\ *Corresponding author
}

\begin{tabular}{l} 
Key w o r d s \\
Microbial, Quality, \\
Physicochemical, \\
Sensory, Fruit juice \\
\hline Article Info \\
\hline $\begin{array}{l}\text { Accepted: } \\
\text { 25 November } 2020 \\
\text { Available Online: } \\
10 \text { December } 2020\end{array}$ \\
\hline
\end{tabular}

\section{A B S T R A C T}

Microbial, physicochemical and sensory properties of mixed fruit juice produced from pineapple, orange, apple and lime was investigated using standard methods. The fruits were sliced, pulped using an electric blender and filtered separately with a clean muslin cloth. The individual fruit juices were blended in ratios, divided into three samples and preserve using high temperature pasteurization at $80^{\circ} \mathrm{C}$ for 15 minutes(HPS), Low temperature pasteurization (LPS)at $60^{\circ} \mathrm{C}$ for $30 \mathrm{~min}$ (LPS) and the third samples was preserve with sodium metabisulphite (SFS). The total viable count ranges from $3.2 \times 10^{3}$ to $4.5 \times 10^{3} \mathrm{cfu} / \mathrm{ml}$. Coliform count ranges from 1.0 to $2.8 \times 10^{3} \mathrm{cfu} / \mathrm{ml}$, fungal count ranged from $1.5 \times 10^{3}$ to $2.6 \times 10^{3} \mathrm{cfu} / \mathrm{ml}$ there was no Salmonella count in all the samples. The $\mathrm{p}^{\mathrm{H}}$, titratable acidity, total soluble sugars and vitamin $\mathrm{C}$ content ranged from, 3.4 to 4.1 , $1.34-1.35(\mathrm{lg} / 100 \mathrm{~g}), 3.4$ to $10.32 \%, 4.33$ to $7.2(1 \mathrm{~g} / 100 \mathrm{~g})$ respectively. Sensory evaluation of the samples revealed that there was significant difference at $(p<0.5)$ in colour, taste and overall acceptability among the mixed fruit samples. Sample HPS (High pasteurized sample) was found to be the most acceptable from all the other samples. However the $\mathrm{pH}$, titratable acidity, vitamin $\mathrm{c}$ and microbial counts recorded lower values Thus, high temperature pasteurization is encourage for longer shelflife of fruit juice samples.

\section{Introduction}

Juices are aqueous liquids expressed or otherwise extracted usually from one or more fruits (Bello et al., 2014). Juices are prepared mechanically by squeezing or macerating the pulp of fresh fruits or vegetables without application of heat or solvent to give an unfermented clouded, unclarified and untreated juice ready for consumption. Diluting or blending is a common practice as many fresh juices are either too acidic or too strongly flavored to be pleasant for consumption (Asha et al., 2014). Fruits are parts of plants that houses seeds or flesh covering of nuts or succulent, they are pulpy in character, often juicy and since the develop from flowers of plant. Fresh fruit and vegetable juices are an important part of modern day diet in many parts of the world as they are rich source of nutrients such as vitamins, minerals and other naturally occurring phytochemicals which are of health and therapeutic benefits (Ukwo et al., 2011). 
The consumption of fruit juices could have both positive and negative effects on the part of consumers. Fruit juices processed under hygienic conditions could play important role in enhancing consumer's health through inhibition of breast cancer, Congestive Heart Failure (CHF) and urinary tract infection (Bello et al., 2014). However, freshly extracted juices may not always be safe owing to the heavy load of microbes. Major ingredients of juices such as water, sugar, natural fruit pulp, etc may also carry some microbial contaminants which may cause spoilage of drinks or gastrointestinal disorders to consumers (Asha et al., 2014).

Fruit juice is a ready and rich sources of vitamins, fiber and mineral salt for human consumption due to its uses as medicine, food and appetites (Ashurst, 1991). Fruits are difficult to keep for a considerable length of time. Thus, ripe fruits are utilized either as fresh fruit or processed into juice and specially product (Fraternale, 2011). Mixed fruit juices are liquid, non-alcoholic drink produced from the blends of fresh fruit juice such as orange, tangerine, banana, watermelon, and pineapple among others (Onwuka et al., 2014). In Nigeria, there is an availability of suitable fruits which could be exploited for juice making such as passion fruit, watermelon, pineapple, banana, and orange among others. These fruits are highly perishable nature (Fish et al., 2002). Large quantities of the fruit are traditionally and commercially processed into the different products such as wine, fruit juice, soft drink, carbonated beverages, and alcoholic drinks which help to prevent post-harvest loss. Fruit and vegetable supply more than $90 \%$ of vitamin $\mathrm{C}$ in human diet (Erentuk et al., 2005). Most fruits are perishable in their natural state after harvest, deterioration sets in almost immediately due to metabolic activities which continue even after harvest. The perishable nature makes it difficult to store and preserved fruit, hence there is gradual loss of flavor and nutritional values. The conversion of fruit juice was originally developed as a result for making use of supplies surplus to the fresh fruits market but while it still fulfill this function. There are also different kinds of tropical fruit available for the production of fruit juices and they are pineapple, orange, apple, lime. All these are used for the different purposes depending on the types of drink that is desired (Tambekar, 2009).

Orange (Citrus sinensis) belong to citrus family from Rutaceae (USDA,2000). Orange are rich in vitamin $\mathrm{C}$ powerful natural antioxidant, folate, dietary fiber, and bioactive compound like carotenoid and flavonoids that prevent cancer and degenerative diseases (Ejaz et al., 2006). Apple fruit is notable for its impressive list of phyto-nutrients, and antioxidants, studies that its components are essential for optional growth, development, and overall wellness. Apples are rich in dietary fiber, which helps prevent absorption of dietary in the gut. Apples are rich antioxidant phyto-nutrient flavonoids and polyphenolics, the total measured anti-oxidant strength and procyanidin B2. (Crandall, 2001). Fresh pineapple is low in calories, nevertheless it is a store house for several unique health promoting compounds, minerals and vitamins that are essential for optimum health. Pineapple fruits contain a proteolytic enzyme bromelian that digests food by breaking down protein. Pineapple is an excellent sources of antioxidant vitamin; vitamin $C$ It contain small amount of vitamin $\mathrm{A}$ and beta-carotene levels (Dull, 2000; Hossain, 2011). All types of juice are inherently unstable, they rapidly undergo microbiological attack by microorganism already present on the fruit or gaining access to the produce during processing, they are also subjected to enzymatic and non enzymatic charges (Fermandes, 2008). Most 
fruits are seasonal crop and must be either part processed for temporary storage or a success with crops must be processed as they come into season (Mc gee; 2004). In Nigeria, most of the fruit drinks are imported. Locally processed fruit drinks are highly needed in order to reduce foreign exchange for importation (Nwachukwu and Aniedu 2013).

The objectives of this research is to produce mixed fruit juice from orange, pineapple, apple, lime subjecting to different treated methods and to determine the microbial, physicochemical and sensory qualities of the mixed fruit juice.

\section{Materials and Methods}

\section{Sources of materials}

The fruits used for the production were purchased from sayedero market Ilaro, Ogun State, Nigeria. All other material/ items were gotten from Food Technology laboratory of Food Technology Department, Federal Polytechnic Ilaro.

\section{Preparation of mixed fruit juice}

The fruits were sorted for wholesomeness, washed in clean water to remove contaminants reduced microbial load. They were peeled, squeezed to extract the juice, sieved to obtained pineapple, orange, apple and lime juice. Apple was washed, peeled, deseeded, blended and sieved to obtained juice. Juices extracted from the three fruits, blended in different proportion of $(40 ; 25: 25: 10)$ to obtain the pineapple, orange, apple and lime mixed fruit juice as in Fig1.

\section{Treatment of fruit juice}

Pasteurization was done for the first and second samples. Sample (HPS) High pasteurization temperature low time at $80 \mathrm{C}$ for 15 minutes, Sample (LPS) Low pasteurization temperature high time at $60^{\circ} \mathrm{C}$ for 30. Third sample (SMS) Chemical preservative (sodium metabisulphite) $0.1 \%$ was incorporated into the fresh mixed fruit juice filled into bottles and capped immediately. All the samples cooled and stored in the refrigerator at $4^{0} \mathrm{C}$.

\section{Microbiological analysis}

The different media used to inoculate the samples were Nutrient Agar (Oxoid) for total viable count (TVC), Potato Dextrose Agar (Oxoid) (supplemented with chloramphenicol to prevent bacterial growth) for total fungal count (TFC), Salmonella-Shigella agar (Antec) for Salmonella count (SC) and Eosin Methylene Blue Agar (Oxoid) for coliforms. The media were prepared according to the manufacturer's instruction. Aten-fold serial dilution of each of the sample was carried out and one (1) $\mathrm{ml}$ from the appropriate dilutions was placed insterile Petri plate before pouring $20 \mathrm{ml}$ of pre sterilized unsolidified agar medium. The sample was properly mixed in the unsolidified agar medium. The agar plates were allowed to solidified and then incubated at $37^{\circ} \mathrm{C}$ for 24 to $48 \mathrm{hrs}$ for bacterial count and at $28^{\circ} \mathrm{C}$ for $3-5$ days for fungal count (Lynne, 2003; Cheesbrough, 2005). Count of sample was performed on two plates of each medium and the mean value recorded as colony forming unit per $\mathrm{ml}(\mathrm{cfu} / \mathrm{ml})$.

\section{Determination of $\mathbf{p H}$}

The ph of the juice was determined using a digital ph meter (pHs-2f harris, England) according to AOAC 2005 method. 50ml of the juice was transferred into a beaker and the $\mathrm{pH}$ was determined after the meter was calibrated using standard buffer solution of $\mathrm{pH} 4.0$ and 7.0. Sufficient time was allowed for equilibration before readings were taken. 


\section{Determination of the total sugar content}

The hand held sugar refractometer was used. The prism of the refractometer was cleaned and a drop of juice was placed on the prism and closed. The total sugar content (brix) was read off the scale of the refractometer when held close to the eye according to the method of (AOAC 2005).

\section{Determination of Titratable Acidity (TTA)}

$10 \mathrm{ml}$ of the juice was pipette into a conical flask and $25 \mathrm{ml}$ of distilled water was added as described by (AOAC 2005). Two hundred meters $(200 \mathrm{ml})$ of $0.1 \mathrm{~m} \mathrm{NaOH}$ was poured into a burrette and was titrated against the sample in the flask using 3 drops of phanolphthalen as indicator. It was titrated until a pink coloration was observed and the corresponding burette reading was taking.

\section{Results and Discussion}

The result of the microbial, Physicochemical and Sensory analysis of the mixed fruit juice are represented in the table 1,2 and Fig 1

Table 1 shows the microbial count $(\mathrm{cfu} / \mathrm{ml})$ of the various mixed fruit juice from Pineapple, oranges, apple and lime samples. Total viable count ranged from $3.2 \times 10^{3}$ to $4.5 \times 10^{3} \mathrm{cfu} / \mathrm{ml}$, Samples HPS (Sample with High pasteurization temperature) has the lowest counts of $3.2 \times 10^{3}$, sample LPS (samples with Low pasteurization temperature) has $4.0 \times 10^{3}$ and $4.5 \times 10^{3} \mathrm{cfu} / \mathrm{ml}$ in sample SMS (Sample with Sodium metabisulphite), the coliform count range from $1.0 \times 10^{3}$ to $2.8 \times 10^{3} \mathrm{cfu} / \mathrm{ml}$ and no growth of Salmonella count in all the samples. The yeast and mold count of the sample range from Nil to $2.6 \times 10^{3}$ cfu/ml from sample HPS - sample SMS respectively. Total viable count analysis of the sample showed HPS has the least total viable count in the range of $3.2 \times 10 \mathrm{cfu} / \mathrm{ml}$ while sample SMS showed the highest count of $4.5 \times 10^{3} \mathrm{cfu} / \mathrm{ml}$ in all the attributed analysed. The total viable counts recorded in the three juice samples were lower counts. This is in agreements with the findings of Nwachukwu and Aniedu (2013), The fungi count shows no growth for the sample HPS and LPS showed the least count of $1.5 \times 10^{3}$ $\mathrm{cfu} / \mathrm{ml}$ while sample SMS showed the highest count of $2.6 \times 10^{3} \mathrm{cfu} / \mathrm{ml}$. The high pasteurize sample had the least microbial count than other samples. This confer that juice can be best preserve with high temperature to have a lower microbial counts. There were no microbial standard set for juice in Nigeria. However, the recommended specifications for fruit juices served in gulf regions indicated that the maximum count permitted for aerobic bacteria was $5.0 \times 10^{4} \mathrm{cfu} / \mathrm{ml}$ and yeast or moulds was1.0 $\times 10^{3}$ cfulml while total coliforms was 100/ml (Ahmed et al., 2009). On the basis of the gulf standards the microbial load in this study is within permissible level. A number factor is responsible for contamination of fruit juice. Most fruit contain bacterial count, due to improper handling, washing of fruits before use can add bacterial and microorganism to the juice been produced and leading to contamination. Properly pasteurized fruit juices are generally considered as safe and very rarely associated with foodborne disease outbreaks. To reduce the use of heat, weak acid preservatives (citric acid, benzoic acid, sulfur dioxide or their combination) are generally added. In addition, refrigeration at $5^{\circ} \mathrm{C}$ or lower has to be applied to control spoilage microorganisms that survive pasteurization.

The physicochemical analysis of the mixed fruit juice are presented in Table 1. It shows that the fresh sample had the highest vitamin $\mathrm{C}, \mathrm{pH}$, titratable acidity, total sugar content. The $\mathrm{pH}$ value of the fruit juice range from 3.4 to 4.1 This falls within the range of $3-5$ for 
fruit and vegetable juices (Akusu et al., 2016; Owolade et al., 2017). This result is also in agreement with the research reports of $3.23-$ 4.08 for different brands of orange juicest has was observed by (Ndife et al., 2013), The $\mathrm{pH}$ is a measure of the degree of acidity or Alkalinity of a product. The $\mathrm{pH}$ value of 3 to 4 may give juice a good potential of inhibiting the growth of pathogenic bacterial (Jay 2000).

There was a slight increase in the TTA from the sample with high pasteurization temperature to the sample preserve with sodium metabisulphite. Titratable acidity is a measure of the predominant acid present in the juice of fruits. Food acids dictate the dominant microflora in foods and to a large extent will determine the shelf stability of the juice; the more acidic the juice, the less susceptible to bacterial action (Ndife et al., 2013).

The total sugar content decreased from 10.34 to $3,4{ }^{0}$ Brix, with the sample with sodium matabisulphite having the least value. Akusu \& Emelike (2018) reported the total sugar content in watermelon and pineapple blends to be $4.50-5.00 \%$ and $6.90-7.70 \%$, respectively Also value recorded by Akusu et al., (2016), were the total sugar content range from 10.20 to $13,00 \%$. These are quite similar to results obtained in the current study. It may be suggested that the increase in the sugar present may be ascribed to the amount of sugar present in the pineapple and apple fruit while the preservative may have been the cause of the reduction of total sugar in sample juice SMS.

Table.1 Microbial analysis of the mixed fruit juice from pineapple, oranges, apple and lime

\begin{tabular}{|c|c|c|c|c|}
\hline Sample & $\begin{array}{c}\text { Total viable } \\
\text { count } \mathbf{c f u} / \mathbf{m l}\end{array}$ & $\begin{array}{c}\text { Coliform count } \\
\mathbf{c f u} / \mathbf{m l}\end{array}$ & $\begin{array}{c}\text { Salmonella count } \\
\mathbf{c f u} / \mathbf{m l}\end{array}$ & $\begin{array}{c}\text { Fungi (mold and yeast) } \\
\mathbf{c f u} / \mathbf{m l}\end{array}$ \\
\hline HPS & $3.2 \times 10^{3}$ & $1.0 \times 10^{3}$ & $\mathrm{Nil}$ & $\mathrm{Nil}$ \\
LPS & $4.0 \times 10^{3}$ & $1.6 \times 10^{3}$ & $\mathrm{Nil}$ & $1.5 \times 10^{3}$ \\
SMS & $4.5 \times 10^{3}$ & $2.8 \times 10^{3}$ & $1.0 \times 10^{3}$ & $2.6 \times 10^{3}$ \\
\hline
\end{tabular}

Key: Mixed fruit juice produced from (Pineapple, orange, apple and lime in ratio $(40 ; 25 ; 25 ; 10)$

HPS: High temperature pasteurized sample at $80^{\circ} \mathrm{c}$ for $15 \mathrm{~min}$

LPS: Low temperature pasteurized sample at $60^{\circ} \mathrm{c}$ for $30 \mathrm{~min}$

SMS: Sodium metabisulphite fresh sample

Table.2 Physicochemical analysis of the mixed fruit juice from pineapple, oranges, apple and lime

\begin{tabular}{|l|l}
\hline Sample code $\quad \mathbf{p}^{\mathrm{H}}$ TSCTTAVitamin C \\
\hline HPS3.4 $\pm 0.01^{\mathrm{ab}} 10.32 \pm 0.14^{a} 1.34 \pm 0.01^{\mathrm{bc}} 4.33 \pm 2.25^{a}$ \\
\hline LPS4.1 $\pm 0.5^{\mathrm{ab}} 10.30 \pm 0.10^{\mathrm{b}} 1.35 \pm 0.7^{a} 5.18 \pm 0.34^{a}$ \\
\hline SFS3.5 $\pm 0.1^{b} 3.4 \pm 0.01^{\mathrm{a}} 1.35 \pm 0.3^{a} 7.21 \pm 1.3^{b}$ \\
\hline
\end{tabular}

Values are means of duplicate determinations. Means in the same column with different superscripts differ significantly $(\mathrm{P}<0.05)$

Key; TSC :Total soluble content TTA: Totaltitratable acidity 
Fig.1 Flow chart for the production of mixed fruit juice

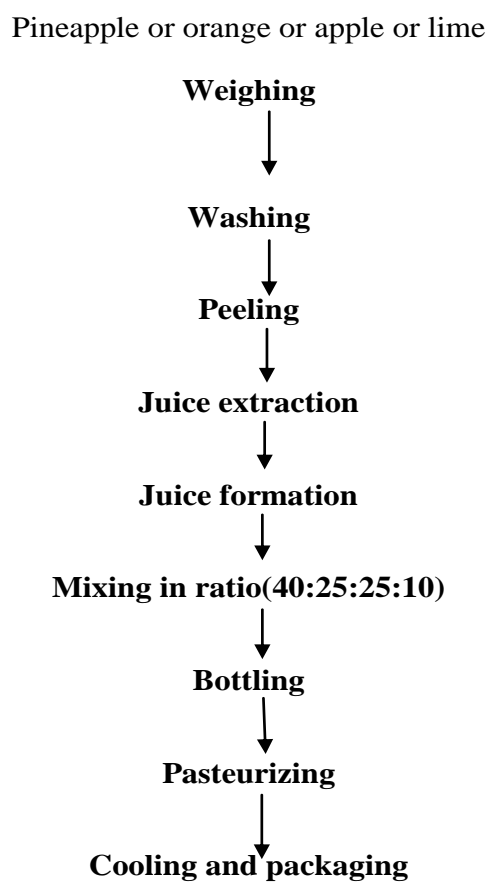

Fig.2 Sensory evaluation of mixed fruit juice from pineapple, oranges, apple and lime

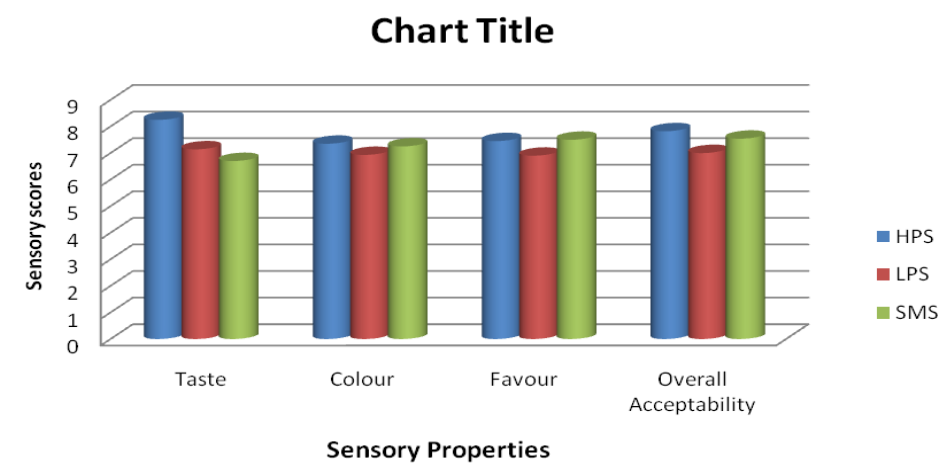

The Vitamin $\mathrm{C}$ content of the samples range from 4.33 to $7.27 \mathrm{mg} / 100 \mathrm{mg}$. Sample SMS has the highest value while sample HPS has the lowest value. This is due to the heat treatment which reduces the Vitamin $\mathrm{C}$ content.

The sensory evaluation result are presented in Fig 2. The sensory taste shows significant differences $(\mathrm{P}<0.05)$, sample HPS has highest score of 8.85 while sample SFS has the least score of 6.7. The colour evaluation result showed that the high pasteurized was highly accepted by the panelist. In terms of the colour, sample HPS has the highest scores while the least score recorded was sample LPS. There was no significant difference in flavours. Sample HPS has the highest scores while LPS has the least score of 6.9.In terms of overall acceptability sample HPS (sample 
with high pasteurization temperature) has the best overall acceptability

In conclusion from the research work of the microbial analysis of mixed fruit juice, sample HP5 had the least microbial counts, highest total sugar content though with low vitamin $\mathrm{C}$ content, which is still in the range of fruit juice and had the best overall acceptability of the samples. Thus, high temperature, pasteurization is encourage for longer shelf life of juice samples.

\section{Acknowledgement}

The Author acknowledgement the assistance of Okeniyi, Eunice. Oluwabusayomi in the laboratory work.

\section{References}

Adubofuor, J., Amankwah, E., Arthur, B., Appiah, F. (2010). Comparative study related to physico-chemical properties and sensory qualities of tomato juice and cocktail juice produced from oranges, tomatoes and carrots. Afr. J. FoodSci. 4 (7), 427-433.

Ahmed MSU, Nasreen T, Feroza B and Parveen S (2009) Microbiological quality of local market vended.

AkusuO.M,Kiin-Kabari, D.BAND Ebere C.O.(2016). Quality Characteristics of Orange/Pineapple Fruit Juice Blends American Journal of Food Science and Technology,, Vol. 4, No. 2, 43-4.7

AOAC (2005). Official Methods of Analysis. Association of Official Analytical Chemists.

Asha, S., Nithisha, K., Niteesha, G., Bharath, K. R., and Ravikumar, V. (2014). Evaluation of microbial quality ofstreet vended vegetable and fruit juices. Int. Res. J. Biol. Sci.,

Ashurst, P.R (1991). History of fruit drinks and food flavouring. Rumbold,New York pp 9-35.

Bello, O. O., Bello, T. K., Fashola, M. O., and Oluwadun, A. (2014).Microbio logical quality of some locally-produced fruit juices in Ogun State, South Western Nigeria. E3 Journal of. Microbial. Res., 2: $1-8$.

Cambridge University Press.2000; Pp. 76 100.

Cheesebrough, M. District Laboratory Practice in Tropical Countries.Parts 2.

Costescu C, Parva D and Rivis A (2006).The determination of some physicochemical characteristics for juice. 12(2)429-432.

Dull G.G (2000). The Pineapple. In: Hulme A.C ed. The Biochemistry of Fruits and Their Products, Academic Press, New York, 303-314. edition. Washington, D. C. USA.

Ejaz S, Ejaz A, Matsuda K, Chae WC. Limomoid as cancer chemopreventive agent. J Sci Food Agric 2006;86:339-45.

Erentuk S, Gualaboglu MS, Gultekin S. The effects of cutting and drying medium on the vitamin $\mathrm{C}$ content of rosehip during drying. J Food Eng 2005;68:513-8.

Fernandes JR F.AN linhares F.E and Rodrigues S (2008) ultrasound treatment of pineapples. Ultrasonic smochemistry15(6) 1049-1054.

Fish WW. Perkins-Veazie P, Collins JK. Quantitative assay of lycopene that utilize reduced volume of orange solvents. J Food Compos Anal 2002;15:309-15.

Fraternale D, Ricci D, Flamini G, Giomaro G (2011). Volatile profiles of red apple from Marche Region (Italy). Rec. Nat. Prod., 5(3): 202-207.

Gulf Standards (2000). Microbiological criteria for food stuffs-part 1. GCC, Riyadh, Saudi Arabia. p. 7-20

Hossain M.A and Rahman S.M.M (2011). Total phenolics flavonoids dantioxidant activity of tropical fruit pineapple. Food Research International, 44, 672-676. 
Hulme (1990). Biochemistry of fruit and vegetables. food journal vol. 1 london.

Nwachukwu, E. and Aniedu, U.i (2013) Evaluation for microbial quality, physicochemical and sensory properties of locally produced fruit-ginger drinks in Umuahia.

Jay J.M. (2000) Modern Food Microbiology. 6th ed. Maryland: Aspen Publishers, Inc.; 2000. p. 289.

lhekoronye A. I. and Ngoddy P.O. (2001): Integrated Food Science and Technology for the Tropics. 1. Edition. Macmillan Publishers pp 180-185.

MC Gee (2004). Food and Cooking ISBN publicationpg 367.

Lynne MA. Food microbiology laboratory. (comtemporary food science) CRC Press,U.S.A.2003 3: 60-64.

Ndife, J., Awogbenja, D., Zakari, U. (2013): Comparative evaluation of the nutritional and sensory quality of different brands of orange-juice in Nigerian market. Afr. J. Food Sci. 7 (12), 479-484. https://doi.org/10.5897/ajfs2013.1060.

Onwuka GI. Food Science and Technology. Lagos: Naphtali Print; 2014. p. 282-7.

Onyekwelu C. N ( 2017) ) Physicochemical Properties And Sensory Evaluation Of Mixed Fruit Juice (Orange, Watermelon, And Tangerine) Using Date Syrup As A
Sweetener. Innovare Journal Of Food Science, Vol 5, Issue 1.

Ratih Dewanti-Hariyadi (2014) Microbiological Quality and Safety of Fruit Juices: Safety and Quality Aticle. Faculty member at the Department of Food Science and Technology and

Research publication at: https://www.researchgate.net/publication $/ 259562067$

Sandeep, M, diwakar A. \& Abhijit G. (2004). Microbial analysis of street vended fruit juice 3,1-3.

Tambekar D.H., V.J. Jaiswal, D.V. Dhanorkar, P.B.Gulhane and M.N.Dudhane1 (2009) Microbial Quality and safety of street vended fruit juices: A case study of Amravati city. Internet Journal of Food Safety, Vol.10, 2009, p. 72-76.

Ukwo, S. P., Ndaeyo, N. U., and Udoh, E. J. (2011).Microbiological quality and safety evaluation of fresh juices and edible ice ssold in Uyo Metropolis, South-South, Nigeria. Int. J.Food Safety, 13: 374-378.

USDA (2014). Nutrition Facts for Carrots, Raw [Includes USDA Commodity Food A099], per 100g, USDA Nutrient Data Base for Standard (10 December, 2014) Reference, Version SR-21.

\section{How to cite this article:}

Noah, Abimbola Aduke. 2020. Microbial Quality, Physicochemical and Sensory Properties of Mixed Fruit Juice Subjected to Different Preservation Methods. Int.J.Curr.Microbiol.App.Sci. 9(12): 3258-3265. doi: https://doi.org/10.20546/ijcmas.2020.912.388 